\title{
Education of Technology For Social Well Being Educational Technology Innovations in Learning and Learning for the social community
}

\author{
Nurliani Siregar ${ }^{1}$, Bangun Munthe $^{2}$, Bertaria .Sohnata Hutauruk $^{3}$, \\ Susy A Sibagariang ${ }^{4}$ \\ University HKBP Nommesen \\ e-mail nurlianisiregar@yahoo.com
}

\begin{abstract}
The purpose of this research is to improve the social welfare of the community through the world of education with the application of Educational Technology Innovation in Learning and Learning subjects. The application of educational technology innovations in Learning and Learning courses begins by activating the role of students of the Faculty of Teacher Training and Education to help children who live in their areas of residence so that free tutoring. Data collected in research and development uses descriptive qualitative analysis of the implementation and results of the development of model design. The development consists of three steps, namely (1) an initial draft consisting of a study of literature, a needs analysis, and documentation, (2) a stage of applying the design model of the technology of learning and learning technology education, syllabus, evaluation, expert validation and revision, (3) the implementation phase which consists of limited trials and revisions, field trials and revisions, and the final model. The product of this research is the Learning and Learning handbook which applications can be used by students and teachers, especially Learning and Learning courses..
\end{abstract}

Keywords: Educational Technology, Learning and Learning, Community Social Welfare, Teacher Training and Education Faculty Students

\section{Introduction}

According to Lindgren learning as a process of behavior change is relatively permanent and the change is due to the interaction of the individual concerned with his environment. Heinich (1999) says that learning is the process of developing knowledge, skills or attitudes as a person's interaction with information and their environment so that the learning process requires the selection, preparation and delivery of information in an appropriate environment and through the interaction of learners with their environment. Gredler also stressed the very strong influence of the environment in the learning process, study learning is not just an academic exercise, it is an important aspect for both individuals and society. Learning is also the basis for the future progress of society. Furthermore, Gagne \& Briggs (2008) explained learning is the result of a pair of stimulus and response which then held a continuous reinforcement (reinforcement). Reinforcement is intended to strengthen the behavior that is internalized in the learning process. The learning process of each person will produce different learning outcomes for that the need for continuous reinforcement to 
experience changes in behavior towards a better. Learning is an activity carried out intentionally or unintentionally by every individual, so there is a change from the unknowing to the knowing, from the unable to walk to being able to walk, unable to read to being able to read and so on. Learning is a process of changing individuals who interact with the surrounding environment in a good or bad direction. Learning is a process of behavior change thanks to experience and practice. That is, the purpose of learning is a change in behavior, both concerning knowledge, skills and attitudes, even covering all aspects of the organism or person. Teaching and learning activities such as organizing learning experiences, processing teaching and learning activities, assessing learning processes and outcomes, all include the responsibility of the teacher. Thus more and more effort learning is carried out so that more and more changes are obtained. Active change means that the change did not happen by itself but was due to one's own effort. In the learning process there must be a goal to be achieved, there are several things that become goals in learning. Classification of learning outcomes according to Benjamin Bloom (Nana Sudjana, 2010: 22-23), namely: 1 . The cognitive domain, with regard to intellectual learning outcomes consisting of six aspects including knowledge, understanding, application, analysis, synthesis, and evaluation. 2. The affective domain, with regard to attitudes consisting of five aspects including acceptance, answers, judgment, organization, and internalization. 3. Psychomotor domains, regarding learning outcomes in the form of skills and the ability to act, covering six aspects, namely reflex movements, basic movement skills, perceptual abilities, accuracy, complex skills, and expressive and interpretive movements. The results of learning become a model in the next learning process. Learning means learning activities carried out by students and teachers. Process learning becomes one system in learning. The learning system consists of several components that interact with each other to obtain an effective interaction. Dick and Carey explained the components in the learning system were learners, instructors (teachers), learning materials and learning environments.According to Reigeluth in supporting the learning process there are three learning variables namely the learning condition variable, the method and the learning outcome variable. The Reigeluth learning variable shows that the learning conditions are the beginning of the learning strategy to achieve learning outcomes. While the learning method emphasizes the components of learning strategies, delivery and management of learning. And to achieve learning outcomes Reigeluth more direct learning models that are effective, efficient and have an attraction Seels and Richey in the book Instructional Technology: The Definition and Domains of the Field, said that development is an area of work in Educational Technology that includes theoretical and practical activities, as well as the fields of design, development, utilization, management and evaluation. Development is one of the domains of educational technology which includes the development of print technology, audiovisual technology, computer-based technology and integrated technology. Learning planning is the activity of projecting what actions will be carried out in a teaching and learning process by coordinating the learning components so that the learning objectives, learning materials, ways of delivering activities (methods, models and techniques), 
and how to measure them become clear and systematic, so that later teaching and learning process to be effective and efficient. The principles of learning planning include: Determining what the teacher wants to do, when and how to do it in the implementation of learning. Limiting targets on the basis of specific instructional objectives and establishing work performance to achieve maximum results through the process of determining learning targets. Develop alternatives that fit the learning strategy. Collecting and analyzing information that is important to support learning activities. Prepare and communicate plans and decisions related to learning to interested parties. The learning planning objectives include: Directing student learning activities and teaching activities of teachers, because the plan has been programmed systematically. Knowing student learning progress because the material to be presented has been planned in detail. Produce a maximum of teaching and learning process because everything has been prepared before the lesson begins. Knowing immediately the success of the teaching and learning process, through planned teaching and learning activities. Give students excitement in learning with the information and relevance of learning objectives. Provide convenience for students in mastering the material because the systematic delivery has been prepared. Learning planning function. Give the teacher a clearer understanding of the goals done to achieve that goal. Help the teacher clarify thoughts about donations. Adding teacher confidence in the values of learning that Assist the teacher in order to recognize the needs Reducing the activities that are trial and error in right. Help teachers maintain the enthusiasm of teaching and always However, this rapid technological development also has negative effects in the social field such as many types of new crimes in cyberspace, lack of privacy space, reduced level of trust in the surrounding environment, reduced sense of concern for others, lack of privacy space etc.In addition to the social field in the cultural field also has negative impacts such as a lack of love for one's own culture, we prefer to study foreign languages rather than our own language, prefer to learn modern dance that comes from outside culture rather than traditional dance which is our own culture, and which is more dangerous to cultural life is the number of tracing other cultures that often occur lately which is very detrimental to the Indonesian people. As we know in today's technology in the developing world is rapidly circulating in the community, almost all aspects of life in today's society all use the very technology. Since the number of new and sophisticated technologies found, almost all social life really needs technology, and is used in various fields such as in education, technology in agriculture, technology in health, technology in sports and what often happens lately is technology in social and cultural fields. In recent developments in technology in the social and cultural fields, it is discussed in society, both young and old alike. This is caused by the use of technology in this day and age to make it easier for people to socialize with one another. One way is to use mobile phones through applications such as Line, WhatsApp, Snapchat, Instagram, Twitter, Facebook, and various other applications. Lots of applications that offer a way to communicate quickly, easily, and without limits today. The continued use of technology can damage relationships between people. For example a family that has a child initially often spends time together 
outside the home. But after the times, each of them uses each other's technologies so as to create an attitude of individualism. But the development of technology also has many positive impacts on society such as information that is very fast and easy to receive, social relations between communities can take place anywhere and anytime, can get to know the culture of other regions very quickly. The development of technology led to the communication revolution and influenced the development of society. Community activities are inseparable from the technology used since BC until entering the current digital millennium era. Ranging from people who rely on simple technology using leaves, clay to write information messages to the public until the use of the most sophisticated technology today. Technology brings developments in society and is shown by changes that occur in political, economic, social and cultural aspects. In the political aspect of information and communication technology that is increasingly advanced to make the media controlled by certain interests which then established the mass media industry and used as an extension of political interests. Not only that, if previously Marx mentioned the dominance of the bourgeoisie over the proletariat which at that time occurred in the industrial era where developing technology was still limited to paper based communication, now power is no longer related to the source of model ownership, but rather to the instrumental reason of the rulers. In the social sphere, technology brings changes in the way of communication in society, organizations /companies and families. If previously the importance of communicating directly was always used by the public in conveying information. Now, without face-to-face-to-face meetings, people can exchange information, parents can also control the whereabouts of their children when they are apart using their cellphones or via video messages. Unfortunately, the ease of communication brings social relations that had become sticky because of technological inventions. People seem to disregard previous social values because they are considered inefficient with the current high level of community mobility. Technology also raises inequality in a society where ownership of electronic devices then classifies certain communities into lower, middle or upper social groups. To realize a society that has a multicultural spirit, learning strategies are needed to support and develop aspects of multicultural education. In this case, educational technology as a field of science can make a major contribution to the development of multicultural education in Indonesia through studies and strategic offerings. which can be used to be able to implement multicultural education in Indonesia. I. Introduction Indonesia is a country rich in diversity and diversity, this is one of the main realities of the nation and traces of the past, now and will never stop until in the future. The development of Indonesia in all fields has led to a clash of civilizations that consciously or unconsciously led to increasing public awareness of ethnicity, culture, culture and religion. This condition has increasingly triggered the emergence of clashes of civilization. The Role of Educational Technology Barbara B. Seels \& Rita C. Richey (1994: 25) The definition of 1994 was formulated in five arable fields (domains) for learning technologists, namely: Design, development, utilization, management, and assessment. Barbara B. Seels \& Rita C. Richey (1994: 27-28) states that the relationship between regions in Educational Technology is synergistic. 
Between one area and another region has a close relationship and are complementary. The discussion of multicultural education in educational technology is part of the design domain, in this case the intention is that multicultural education is a process for designing learning that is acceptable to all and does not cause divisions. Design is actually a process of specifying the conditions for learning. This design domain includes at least four areas of theory and practice. In this case multicultural education in the study of Educational Technology is the development of the learning system design, where learning is an organized procedure that includes steps of analyzing, designing, developing, implementing up to the stage of evaluating learning. Educational technology can also advise on the application of sociocultural learning theory in multicultural education, as well as how it can be applied and what learning strategies can be used. Not only in the design domain, educational technology can also provide its role by utilizing other existing domains, even all domains in educational technology. Because basically the domains in educational technology are interconnected, including with social learning.

\section{Significance of the study}

The results of this study aim to innovate learning through educational technology for social communities. Through learning and learning courses, it is hoped that teacher and faculty education students have capital about learning educational technology that students will prepare in the field to prepare students to apply educational technology innovations to the social community. So that the social community does not misuse technological advances without being directed towards better and more correct education. For teacher and education faculty students that learning design is able to make students become professional students in designing educational technology that will be confronted with the progress of the industrial revolution era 4.0. This is where students must be able to produce a learning design for social communities, through learning and learning courses. The role of the university is also needed to prepare science facilities that are updated with technological advances in education and are updated with the social needs of the community.

Scope and Limitation of the study

In accordance with the results of this study, this study is limited in space, time and funds is only limited to learning educational technology innovation for the social community through learning and learning courses. In the 5th (fifth) semester students, 2018/2019 academic year of the Christian Religious Education study program, faculty of education and education. Because in this semester study and learning courses can be applied by students as general subjects for all students of the teaching and education faculty but this research is limited to the Christian religious education study program. 
Setting of the study

The study was conducted at the FKIP Nommensen Pematangsiantar Campus. The selection of research sites is determined intentionally (purposive). The time of the study began in September 2018 until February 2019. The samples in the study were all PAK students who took study and learning courses, the sample in the study amounted to 80 PAK students. Samples are taken randomly and sample sizes are taken proportionally.

\section{RESEARCH DESIGN AND METHODOLOGY}

The research method used is survey research methods, and the study of causal relationships. This study examines and analyzes direct relationships that run in the same direction or called causal relationships, this relationship is called path analysis. Furthermore Ferdinand, said to see the causal relationship to be tested in order to facilitate researchers better illustrated by the path diagram. In this case the relationship between research variables and measure the effect of one variable on other variables. According to Kerlinger, path analysis as a technique for studying causal relationships in correlational research. In this case based on the method used by the objectives to be achieved in this study and also based on some opinions of experts, the method used in this study is a survey research method with path analysis. The variables to be analyzed consist of four variables, namely: 1 . Study and learning; 2. Educational Technology; 3. Social Society 4. Teacher training.

\section{FINDINGS AND CONCLUSIONS}

Data needed for this study includes primary data and secondary data. Primary Data includes: 1. Learning and learning; 2. Educational Technology; 3. Social Society 4. Teacher training. The instrument implementation procedures are: (a) determining the trial respondents; (b) the implementation of the test; (c) instrument analysis. The instrument development process begins with determining respondents then continues with the preparation of instruments that refer to the indicators of each variable. The purpose of testing the instrument is to test the validity (validity) and reliability (reliability) of the items of the instrument that will be used in research. Instrument trials were conducted on respondents who were not included in the study sample. According to Arikunto, the validity of the instruments developed needs to be tested. Furthermore, according to Singarimbun, the trial sample should be outside the study sample, but the situation is more or less the same as the research sample with 30-50. Validity testing to see the extent to which an instrument can measure what it wants to be measured and seen in the validity and reliability of the instrument. Kerlinger, argues that there are three main ways to see the validity of an instrument are as follows: (a). construct validity, (b). validity on the basis of criteria and (c). content validity. In this study using construct validity means that the preparation of instruments based on theoretical assessment, a good instrument is conceptually said to 
have good construct validity, item analysis needs to be done by correlating the scores of each item with the total score, to get valid items. The purpose of the trial data analysis is to have valid items and determine the reliability of the instrument, where the instrument must meet two conditions, namely valid and reliable. This means that items based on the theory and opinions of researchers have been grouped into aspects that want to be investigated and these items need to be tested empirically. The test is carried out to see whether the questions have really measured what must be measured. The validity of performance instruments, emotional intelligence, innovation and organizational commitment were tested by using the correlation coefficient between the item scores and the total score (r count) through the Product Momemt (Person) correlation technique. Analysis was carried out on all instrument items. The testing criteria by comparing the price of $r$ count with the price of $r$ table with $\alpha=0.05$. Instrument reliability testing is useful to see the consistency of answers given by toddlers and their mothers. Data analysis using * Alpha Cronbach *. Thus instruments that have undergone a trial process and show high validity and reliability, then these instruments can be used in collecting data needed in research.

\section{RECOMMENDATIONS}

Educational technologists hope to give more attention to multicultural education by conducting in-depth studies of multicultural education. Will it be applied as a model of learning or multicultural education will only be applied as a spirit of education without measurable tangible forms. All parties, related to education be it the government, agencies or the community must support each other, before this multicultural education can be fully implemented, all elements should bring up this multicultural education in daily life as a multicultural spirit. The current condition of education in Indonesia is no less severe than social, political and economic conditions. It is common knowledge that education in Indonesia is experiencing a setback and it is not impossible this is also the cause of the nation's moral degradation. Yet according to Sumitro, education is a conscious effort to develop the potential of humans. When viewed from this understanding, education should be able to provide solutions to these problems and improvement in education is the main thing that must be done, one of them by trying to apply an educational model that can make people aware of the importance of the meaning of differences. The importance of the role of students in influencing learning and learning subjects later to become educators who are innovators for the multicultural social community of the Indonesian nation. The importance of the role of students in influencing learning and learning subjects later to become educators who are innovators for the multicultural social community of the Indonesian nation.

\section{REFERENCES}

Charles M. Regeluth, Instructional Design Theories and Models, An Overview of Their Current Status, (New York: Routledge, 1999). 
Dick Walter, Lou Carey, James O.Carey, The Sistematic Design of Instruction, (New Jersey: Pearson, 2001).

Henry Clay Lindgren, Educational Psychology in the Classroom, (Toronto : John Wiley \& Sons, Inc., 1976).

Heinich, Robert, et al, Instructional Media and Technology for Learning, (New Jersey : Prentice Hall, 1999).

Gredler, Margareth E. Learning and Instruction : Teori dan Aplikasi, (Jakarta : Kencana, 2011).

William J. Rotwell dan Caroliyn K. Human Performance Improvement Houston Texas:Guif Publishing Companny, 2000.

Gagne, Briggs J, Principles of Instructional Design, Second Edition, (New York: Holt Rinehart and Winston, 2008).

Mark A Stiffler, Performance: Creating the Performance-Driven organization (New Jersey: Jhon WilleySon, Inc, Hoboken, 2006

Michaeal Armstrong dan Angela Baron, Performance Managemen London: Institute of Forsonal and Development. 2001

Stephen P Robbins (2), Essentials of Organization Behavior (New Zealand, PrenticeHall, 1984

James J.Gibson, Jhon Ivancevvick, James H. Donelly, Organization: Behavior, Structure, Proceses Bew York: Mc Graw-Hill, Companies, Inc, 2006

Sudjana, Nana. 2010. Penilaian Hasil Proses Belajar Mengajar. (Cet. XV). Bandung: PT. Ramaja Rosdakarya.

Handoko,H.T. Managemen Personalia Dan Sumber Daya Manusia. Yogyakarta: BPFE, edisi ke 2, 1996

Patton, Patricia, EQ Pelayanan Sepenuh Hati, Jakarta: Putaka Delapratasa, 2000

Paul Hersey dan Kenneth H. Blanchard, Manajeman Perilaku Organisasi: Pendayagunaan sumber daya manusia, terjemahan Agus Dharma . Jakarta: Erlangga, 1986 